Commonwealth Council for Scientific and Industrial Research. Many years will be required for the evolution of an animal suitable for northern tropical con. ditions but success, if attained, will be of considerable importance to many parts of the Empire.

\section{Coloration Problems in Animals}

ALL who are concerned with the problems raised by the coloration of animals will be interested in the announcement that two hog-deer (Cervus porcinus) have just been born at the Gardens of the Zoological Society of London. This animal, of about the size of a roe-deer, has a more or less conspicuously spotted coat in the summer, and one of a uniform brownish hue speckled with white in the winter. But the young are heavily spotted, as with our fallow and red-deer, the spots serving to form a 'concealing' coloration. Another coloration problem, and in a way yet more interesting, now presents itself in the sixteen flamingoes just purchased and sent to the Society's park at Whipsnade. These birds lose much of the brilliance of their pink coloration in captivity. Careful note should therefore be made of the intensity of pigmentation of the new arrivals. It has been stated that birds in the London Gardens recovered their lost brilliance when they were turned out into a paddock affording free access to a large pond, well-stocked with small crustaceans. In the gardens of the New York Zoological Society an interesting experiment was made, years ago, on the beautiful rosy flamingo (Phonicopterus ruber) which, in successive moults during captivity, became paler and paler, and finally almost white. By mixing a harmless dye with the food the fading process was considerably lessened, while some retained their original full colour for years. What was the 'harmless dye', and was it continuously administered ? Under the more favourable conditions at Whipsnade, perhaps these birds may breed. In this event a valuable opportunity will be furnished to mark the effect, if any, of climatic influence, and food, on the coloration in their progeny.

\section{Australian Sector in the Antarctic}

THE Australian National Research Council is very much gratified at the announcement that an Order in Council has been issued by the British Government affirming that His Majesty the King has sovereign rights over the antarctic territory, other than Adelie Land, south of lat. $60^{\circ} \mathrm{S}$., between long. $160^{\circ}$ and $45^{\circ}$ E., and placing such territory under the authority of the Commonwealth of Australia from the date on which the necessary legislation is passed by the Commonwealth Parliament. Seven years ago, during the presidency of Sir David Orme Masson, the Research Council urged that sanction be sought for Australian administration of that part of the continent between long. $160^{\circ}$ and $90^{\circ} \mathrm{E}$. The matter was discussed at the Imperial Conference in 1926 when it was placed on record that there were certain areas to which British title existed by virtue of discovery. More thorough exploration of this 'Australian sector' was, however, obviously desirable and to that end the Governments of Great Britain,
Australia and New Zealand, with liberal financial aid from Sir MacPherson Robertson of Melbourne, fitted out the "Discovery" expeditions under Sir Douglas Mawson in the seasons 1929-30 and 1930-31. These explored the greater portion of the sector between long. $160^{\circ} \mathrm{E}$. and $45^{\circ} \mathrm{E}$. including Enderby Land, Kemp Land, Queen Mary Land, King George V Land and new areas to the east of Kemp Land which were named MacRobertson Land and Princess Elizabeth Land. Australia will now presumably assume a measure of responsibility for developing and regulating existing and possible industries in the sector, including the enforcement of the International Convention on Whaling.

\section{International Cloud Photography}

Tнस intensive international study of meteorology during the Second International Polar Year, 1932-33 includes also the sky, and General Delcambre, president of the International Commission for the Study of Clouds, selected two periods for specially detailed investigation in France and neighbouring countries. The first was on April 12 and 13, while the second is arranged for July 12 and 13, 1933, and General Delcambre has asked for material from England. Should conditions on July 12 and 13 be suitable, meteorologists with cameras are asked to take at least three cloud photographs each day, as near as possible to the hours of 8 a.m., 2 p.m. and 7 p.m. B.S.T., and others at intermediate hours whenever the general character of the sky changes. The purpose of the photographs is to represent the changes of the sky as a whole, and cloud-systems should be photographed rather than individual clouds, using, for preference, a wide-angle lens. Artistic merit is a secondary consideration; the prints should show as much detail as possible, but should not be re-touched. Filters should be used if necessary to bring out the structure. It is important that the following information should be given on the back of each print : name and address of the photographer, place where taken, date and time. It is desirable also that notes should be added as to the fraction of the sky covered by cloud, the nature of the clouds in the part of the sky not included in the photograph, the direction in which the camera was pointing and the approximate elevation above the horizon. Prints, suitably packed, should be addressed to: M. le Ministre de l'Air, Office National Météorologique, 196 rue de l'Université, Paris 7, and in the corner should be written "Année des Nuages".

\section{Trevithick Centenary Commemoration Programme}

THE centenary commemorations of the death of Richard Trevithick will be held on April 22, 23 and 24. On Saturday afternoon, April 22, a demonstration will be held at Camborne, where Trevithick made his first experiments with a steam road carriage, and on Sunday afternoon a memorial service will be held in the Tregajorran Methodist Chapel, in the parish of Illogan, Cornwall, his birthplace. On Sunday morning a memorial service will be held at 11 a.m. in Dartford Parish Church, Kent, where the preacher will be the Right Rev. the Lord Bishop 
of Rochester. At the close of this service an address on Trevithick will be given by Mr. L. St. L. Pendred, and a wreath will be placed on the memorial which recalls Trevithick's death at the Bull Inn, Dartford, on April 22, 1833. At evensong at 3 p.m. in Westminster Abbey on Sunday, special reference will be made to the centenary by the preacher, the Ven. Archdeacon V. F. Storr, and at the end of the service a chaplet will be placed beneath the Trevithick window in the north aisle of the Abbey. Finally, on Monday, April 24, at 6 p.m., a memorial lecture will be delivered by Prof. C. E. Inglis, at the Institution of Civil Engineers, Great George Street, S.W.1, by kind invitation of the Council. The chair will be taken by Sir Murdoch Macdonald.

\section{Unemployment and the Schools}

AT the National Union of Teachers' annual conference on April 15 the new president, Mr. H. N. Penlington, of Hemsworth, Yorkshire, opened his address with the declaration that unemployment is the outstanding problem of our age; and this leitmotif dominated the rest of his discourse under the headings of school objectives, school buildings and school staffs. With the ever-increasing displacement of human labour by machinery, leisure seems destined to bulk more and more largely in human life, and it follows that preparation for life must increasingly include equipment for commendable uses of leisure. Unemployment in the building trade could be substantially relieved by carrying into effect school building programmes in respect of more than fourteen hundred schools which are admittedly insanitary or in other ways totally unfit for their purpose. Not less urgent is the need of relief of overcrowding of classes, in nearly eight thousand of which the enrolment exceeds fifty pupils. Meanwhile, the number of unemployed teachers grows and is expected to reach between two and three thousand by September next. If the school-leaving age should remain unchanged, the number of 'school-leavers' this year will be about half a million-an exceptionally large number-and a large proportion of these must go to swell the numbers of the unemployed. The time is opportune, Mr. Penlington suggested, for raising the school-leaving age, and he emphasised the dangers of an unenlightened and reactionary policy spreading discontent, already rife, on account of the 'cuts' in the Burnham scales.

\section{Herrings and the Origin of Petroleum}

IT would seem at first a far cry from a modern herring catch to petroleum genesis, but a recent discovery off the coast of Alaska proves this to be by no means the case. Some twenty or thirty years ago a boat loaded with herrings was wrecked off Admiralty Island, Alaska, and recently samples of the sea deposits, near to where the wreck oceurred, were dredged up and sent to the United States Geological Survey in order that an analysis could be made of an unusual waxy substance which they contained. The investigation was in charge of Dr. R. C. Wells of the Survey, who proved that the wax was a complex compound formed of decom. position products of the fat in the fish, combined with calcium and magnesium salts of the sea-water. It was further found that high-temperature distillation of this wax gave rise to an oil having affinities with petroleum. In all theories of organic origin of petroleum the most difficult part to understand is precisely how the original substance underwent conversion into the hydrocarbon oil which we recognise in crude petroleum and, while we may visualise the environment under which these changes took place, the actual chemical mechanism in. volved is far more difficult to conceive.

As a report issued by Science Service (Feb. 14) states in connexion with this matter, the fact that the fatty acids formed by decomposition of the fish united into a complex waxy salt with minerals in the sea-water suggests that something of the same sort may have happened in the ancient seas in which petroliferous deposits have been laid down. The only criticism we have to make in this instance is that practically all scientific evidence available tends to show that the time factor is of fundamental importance in the production of petroleum, quite apart from the environment in which it may have been conceived. In this particular illustration, it would seem that comparatively little fundamental change could have taken place in the organic substance deposited by this wreck, and we question whether the results of distilling this wax-like material are really indicative of more than would be expected from interaction between animal substance and sea salts, interactions which must, in point of fact, be constantly in process in every sea and in all kinds of environments.

\section{Mechanical Transport in India}

During the last forty years, railways have been a great boon to India, but now their practical monopoly is being seriously challenged by vehicles propelled along roads by internal combustion engines. The paper read to the Indian Section of the Royal Society of Arts on March 10 by Col. F. P. Barnes on the development of mechanical transport is therefore a timely one. He computes that the number of motor vehicles in India is about 160,000 and is rapidly increasing. But this only gives 1 vehicle for every 2,000 inhabitants. This compares with 1 in 5 in the United States and 1 in 32 in Great Britain. There is thus plenty of room for development. Amongst the advantages of motor transport are that it employs a large number of people, it adds to the amenities of life and has a civilising effect. It now gives employ. ment to about 200,000 people in India. Instead of using the tonga and bullock wagon, the business man uses a car and can cover a much larger area in a much shorter time. He can also send his family to the hills in comfort. The eivilising effect is shown in Waziristan, where a great circular road has been constructed running through a country of tribesmen who, a few years ago, were formidable enemies of the British. The road was largely constructed by men who had fought against the British and some of them 